
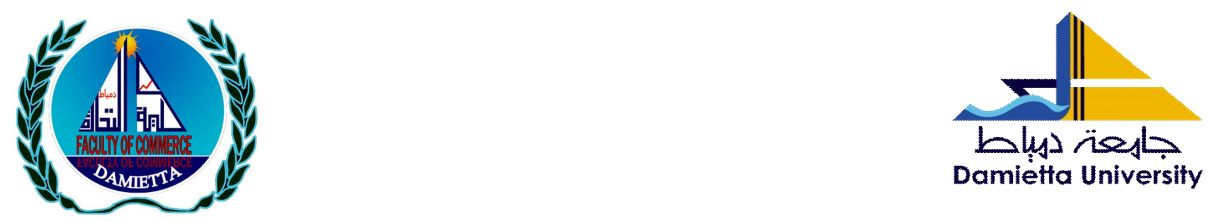

\title{
Does middle class boost an institutional reform? Evidence from selected Arab Countries
}

\author{
Prepared by \\ Dr. Abeer Mohamed Ibrahim Rashdan \\ Lecturer of Economics \\ Future University - Egypt \\ abeer.rashdan@fue.edu.eg
}

Scientific Journal for Financial and Commercial Studies and Researches (SIFCSR)

Faculty of Commerce - Damietta University

Vol.3, SNo.1, Part 1., January 2022

APA Citation:

Rashdan, A. M. I. (2022). Does middle class boost an institutional reform? Evidence from selected Arab Countries, Scientific Journal for Financial and Commercial Studies and Research, Faculty of Commerce, Damietta University, 3(1)1, pp. 429-445.

Website: https://cfdi.journals.ekb.eg/ 
Scientific Journal for Financial and Commercial Studies and Researches

(SJFCSR) Faculty of Commerce - Damietta University

\title{
Does middle class boost an institutional reform? Evidence from selected Arab Countries
}

\author{
Dr. Abeer Mohamed Ibrahim Rashdan
}

\begin{abstract}
The study seeks to investigate the link between the middle class and institutional consequences in four Arab countries. The study deploys a mixed effect model to measure whether increasing the size of middle class would have a causal effect on institutional outcomes in three important areas: health and education, market-oriented and governance during the period (1990-2015). Finding that larger middle class (proportion of people earning between $\$ 4$ - \$13 a day), has negative influence on each of health, tariff, education, and government effectiveness. Also, it has no significant influence on rule of law and corruption.
\end{abstract}

Key Words: Middle class, economic development, governance.

$$
\text { JEL: 01, } 043
$$

\section{Introduction}

Political change in the Arab region in the past has given rise to new thinking, especially the changes were not initiated by the poor class, but by the middle class, which Birdsall (2011) called them the catalyst middle class. One of plugging region is Middle east and North Africa that according to Ravallion (2010) its estimates have a high population density which can be considered middle class as it has increased from $75.5 \%$ of the population to $78.7 \%(1990-2005)$.

Types of theories show a positive impact on the rise of middle-class size on economic and social aspects that can transmitted through many channels; growth, accumulation of human capital, access to credit markets and restructuring the distribution of income due to economic and 


\section{Dr. Abeer Mohamed Ibrahim Rashdan}

social growth (Benhabib et al., 2011; Acemoglu et al., 2008; Epstein et al., 2006).

The purpose of the study is to examine the link between the size of middle class and institutional outcomes in four Arab countries. To what extent have these economies seen a rise in globalization and to what extent have these growths led to the transformation of institutions and policies in three areas: quality of governance, social health and education policy, and market-based economic structure? The Arab countries which will be studied are Egypt, Tunisia, Jordan, and Morocco. The analysis is related to literature investigating the relationship between three main variables; middle class, institutions, and economic growth (Dollar and Kraay, 2002; Lopez and Serven, 2009). Emerging, a critical question; Is rising incomes in middle-income Arab countries increasing the size of the middle class and does this plugging of middle class share would bring any institutional improvement?

The study uses a panel database containing information about income and expenditure, from the poverty data of the world bank PovCal. In addition to social and political indicators. The study came out with unusual results, that middle-class emergence in Arab countries was not followed by the desired social, economic, and political outcomes.

The structure of the study as follows; the second section provides a definition review of middle class, regional comparisons, and measuring the size the middle class in the selected countries. The third section; presents data and methodology. Finally, empirical results the conclusion.

\section{Section Two:}

\subsection{Defining the middle -class (MC)}

Up till now, the meaning of the middle class is still very debatable; there is certainly no consensus among scholars on the precise meaning of who becomes a middle class citizen and what might be the key features of this category. However, escape from poverty is still the traditional way of moving a person to a higher level to be a middle-class citizen.

Income is still the easiest way to determine the lower and upper thresholds of the MC. The most undisputed view of how to choose the lines and as a result how it would accurate in use, and capture the true 
Scientific Journal for Financial and Commercial Studies and Researches

(SJFCSR) Faculty of Commerce - Damietta University

situation of this class, whether economic, social or political. However, to define and measure the identity of the MC, it's crucial to know the purpose of its measurements and its relationship to the underlying causes, economic growth, democracy, inequality, job market, social mobility and other political issues. Adding some difficulty to the process of estimating is which line will be used in estimates (national or global poverty line, middle, or income). There are three traditional methods of measurement: absolute, relative and hybrid. Choosing which is more appropriate and more accurate between methods depends on measurement purposes. Just by looking at the following lines it will review the three main methods.

Firstly, the absolute -Based Income-Based Income Framework (PPP has been adjusted) which raises many conflicting opinions, in addition to the diversity of development rates between the countries. Scholars who support this approach, such as Milanovic (2002), use household survey in 114 countries, where the lines are set to be the average poverty for those who living in Brazil and Italy, to be fixed between (\$12- \$50) per day (2000 PPP), they came out that only 11 percent of the world's population considering middle-class. The World Bank (2007) defines the middle class, as the per capita income is between $(\$ 4,000-\$ 17,000)$. This means that the richest people in less developed countries are in the middle of the world, while the richest people (per capita income is more than a dollar. 17,000) live in the western and OECD countries. Homi \& Gerts (2010) use a daily expenditure threshold of between $(\$ 10-\$ 100)$. the lower line is the average poverty line in Portugal and Italy, the top line was twice the median income of Luxemburg. Applying these lines to 145 countries, they found a significant increase in $\mathrm{MC}$, that would occur mostly in Asia, especially in China. Economists have followed the same pattern as Banerjee and Duflo (2007) using daily personal use $(\$ 2-\$ 4)$ or $(\$ 6-\$ 10)$, arguing that having a good job is essential to get better education and health care that might improve the wellbeing of citizen that eventually push for selfemployment.

Taking a broader view Birdsall (2010) rejects the notion that anyone escaping from poverty is in the middle. Taking the lower line is daily $\$ 10$ (2005 PPP) to be considered the lowest income can a person earn to have at least a degree of economic security, but the upper 


\section{Dr. Abeer Mohamed Ibrahim Rashdan}

threshold is who below the 95th percentile of the income distribution. However, taking a $\$ 10$ per day is very lower line for OECD countries where national poverty lines are defined relatively to the income and considering a very high line to the poor countries. The second approach is based on a median-sized, but this line can be very problematic with having a different median line for each country. Also, Birdsall et al. (2000) uses the thresholds of profitable people between $75 \%$ and $125 \%$ of medians. The same token by Easterly (2001) for those who are between 20 and 80 percent in the average distribution of consumption, shows that the extra-income allocation controlled by the three middle quintile promotes economic growth. A mixed view by Ravallion (2009) uses a hybrid method; looks entirely in the Absolut poverty line but may be related to its use. Ravallion lays the bottom line for $\$ 2$ a day in the 2005 PPP which is among the top 70 countries facing national poverty, with the top \$13 per day representing US national poverty line. According to Ravallion's estimates $\mathrm{MC}$ in developing countries grew from $32.8 \%$ in 1990 to $48.5 \%$ of the population in 2005 . Then, based on the above no clear division of income has been satisfactory.

\subsection{MC in Arab Rigion}

No doubt that poverty line can be very deceptive in the Arab region, but also the measurement of $\mathrm{MC}$ is also deceptive. On one hand by applying world bank poverty line $\$ 1.25$ a day, the Arab region shows the lowest poverty rates of almost $25 \%$ in (2000-2009). While using the high poverty line about $\$ 3$ a day, the level of poverty in the Arab region is higher than

the average of developing regions $(65 \%)$ for the same period of time. Similarly, according to the MC scale, as shown in Table (1), the middle Arab region is the highest in the whole range, using Ravallion's limit to be higher than other regions, reaching about $79 \%$ and can be up to $80 \%$ by bank lines. Asian development ( $\$ 20-\$ 2)$. Compared to the Homi cut, only about $5 \%$ of the population of the region. But this consolidation image hides more than what we reveal, the average GDP per capita increased by an average of 2 percent per annually in Arab countries during the 1990s and 2000s, while the per capita growth rate on household expenses was only 1.3 per cent, indicating that growth has never been translated into higher incomes or housing expenditure for 
Scientific Journal for Financial and Commercial Studies and Researches (SJFCSR) Faculty of Commerce - Damietta University

many people in region, especially the middle class who have supported the poor to form a new coalition, No doubt there is a middle class emerging, not only in terms of income-based limitations, but recent political changes have attracted the attention of this class, which will need to investigate the formation and not the size of this new class. With regard to the Arab region there may be a need to add features and key elements to this emerging class such as; political participation, institutional framework and democracy.

\section{Table (1) Middle class - Regional Comparison}

\begin{tabular}{|c|c|c|c|c|c|c|c|}
\hline Region & & $\begin{array}{c}(0.75-1.25) \\
\text { median }\end{array}$ & (\$13-\$2) & $(\$ 20-\$ 2)$ & $\begin{array}{c}\text { (\$13- Ho } \\
\text { NPL) }\end{array}$ & $\begin{array}{c}\text { (90th- } \\
\text { Ho_NPL ) }\end{array}$ & $(\$ 100-\$ 10)$ \\
\hline \multicolumn{8}{|c|}{ Arab Countries } \\
\hline & $1990 \mathrm{~s}$ & 32.4 & 64 & 65.6 & 66.5 & 59.8 & 3.9 \\
\hline & $2000 \mathrm{~s}$ & 37.1 & 78.6 & 80.2 & 77.5 & 70 & 4.1 \\
\hline & Change \% & 14.5 & 22.8 & 22.3 & 16.5 & 17.1 & 5.1 \\
\hline \multicolumn{8}{|c|}{ East Asia \& Pacific } \\
\hline & $1990 \mathrm{~s}$ & 36.4 & 33.7 & 33.9 & 39.7 & 78.1 & 0.6 \\
\hline & $2000 \mathrm{~s}$ & 31 & 55.7 & 74.2 & 83.9 & 72.9 & 2.6 \\
\hline & Change \% & -14.8 & 65.3 & 118.9 & 111.3 & -6.7 & 333.3 \\
\hline \multicolumn{8}{|c|}{ Eastern Europe } \\
\hline & $1990 \mathrm{~s}$ & 32.9 & 80.8 & 84.8 & 66.2 & 62.2 & 8.3 \\
\hline & $2000 \mathrm{~s}$ & 33.7 & 70.1 & 85.3 & 59.1 & 77.2 & 26.5 \\
\hline & Change $\%$ & 7.8 & 3.4 & 0.4 & 17.2 & 27.7 & 19.8 \\
\hline \multicolumn{8}{|c|}{ Latin America \& Caribbean } \\
\hline & $1990 \mathrm{~s}$ & 20.67 & 65.69 & 77.49 & 38.95 & 44.1 & 14.46 \\
\hline & $2000 \mathrm{~s}$ & 22.29 & 67.92 & 77.82 & 45.64 & 56.32 & 17.32 \\
\hline & Change $\%$ & 7.84 & 3.39 & 0.43 & 17.18 & 27.71 & 19.78 \\
\hline \multicolumn{8}{|c|}{ South Asia } \\
\hline & $1990 \mathrm{~s}$ & 35.98 & 20.42 & 32.23 & 56.03 & 46.19 & 0.3 \\
\hline & $2000 \mathrm{~s}$ & 39.6 & 32.23 & 33.47 & 70.87 & 61.26 & 0.7 \\
\hline & Change $\%$ & 10.1 & 57.8 & 3.8 & 26.5 & 32.6 & 133.3 \\
\hline \multicolumn{8}{|c|}{ Sub-Saharan Africa } \\
\hline & $1990 \mathrm{~s}$ & 29.9 & 22.3 & 22.4 & 45.4 & 35.7 & 0.8 \\
\hline & $2000 \mathrm{~s}$ & 31.5 & 34.3 & 34.7 & 58.3 & 49 & 1.1 \\
\hline & Change $\%$ & 5.4 & 53.8 & 54.9 & 28.4 & 37.3 & 37.5 \\
\hline
\end{tabular}

Arab Region; Djibouti, Mauritania, , Egypt, Jordan, Syrian Arab Republic, Iraq, Sudan, Palestine, Yemen, Morocco, Tunisia

Author's calculation based on data of 67 developing countries (Povcal data). 


\section{Dr. Abeer Mohamed Ibrahim Rashdan}

\section{3: MC for the selected countries}

Looking at $\mathrm{MC}$ in the four selected countries, figure one depicts the estimated size of MC according to the availability of households' surveys. The used benchmark was from \$4 to \$13 using ILO 2014 thresholds. By using fixed lines, the main observation is the consistent bulging of middle class through the last two decades. This confirms the raise of this class in the region, middle class represents $65 \%, 28 \%, 42 \%$ and $62 \%$ in Jordan, Egypt, Morocco and Tunisia respectively. This estimation is consistent with Ali (2010), where the results have shown in five countries (Egypt, Jordan, Morocco, Tunisia and Yemen), MC was amounted to $79 \%$ of the total population in the mid-2000s, where this percentage kept its stability since the mid-1990s. Ali's estimations used the national poverty line (converted into PPP\$) as a lower bound while using a $\$ 13$ per day as the upper one to measure MC .Inevitably using national poverty line as a lower MC threshold, expected to find a large section of MC population falls just above the poverty line but the caveat is how this class is vulnerable to slipping into poverty a gain so easy due to any slight economic shock.

Figure (1) MC size

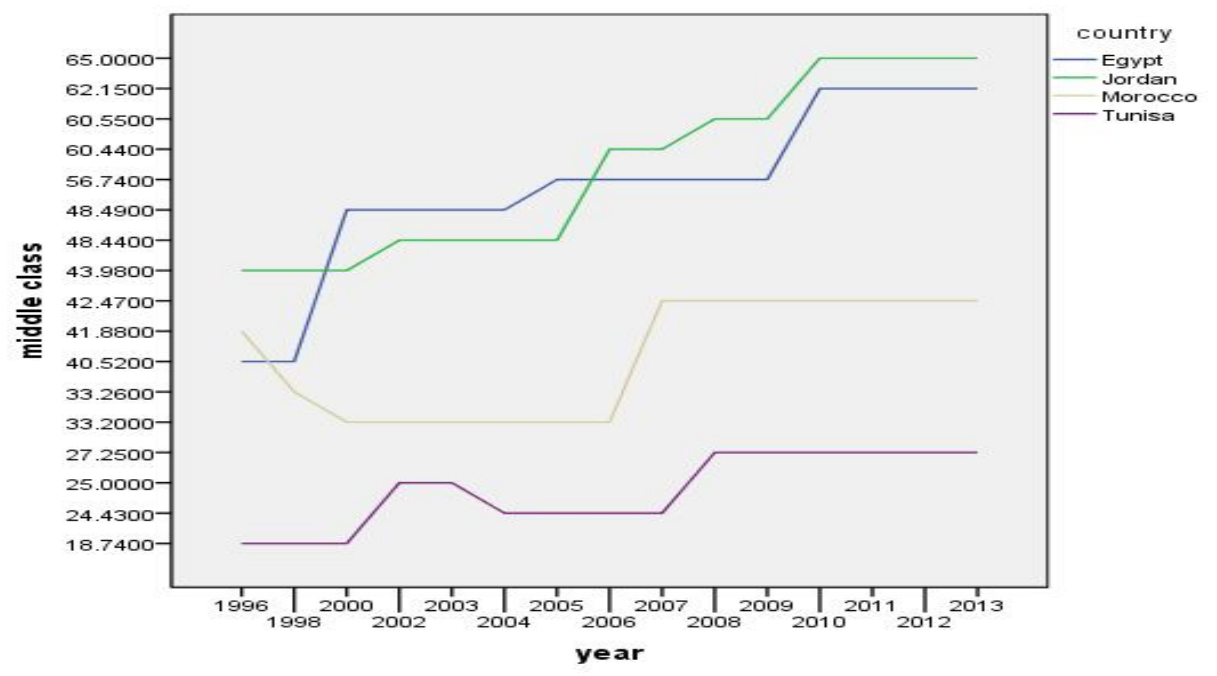

Source: author's allocution, povcal World Bank data 
Scientific Journal for Financial and Commercial Studies and Researches

(SJFCSR) Faculty of Commerce - Damietta University

\subsection{Quick glance at the four selected countries income distribution}

The four countries are characterized with same economic or political changes since 1990. Egypt and Tunisia have witnessed the same economic reform and political uprising at the same time, while Morocco and Jordan have experienced an economic transformation. Despite these economic reforms, the four countries were characterized by a high volatility of economic growth, which could be harmful for the poor and vulnerable middle class. Figure (2) depicts the real GDP growth; unfortunately, any upward movement to any country was curbed by the financial crisis by mid-2008. Economic growth still the main driver of getting poor escape from poverty to be moved to the higher class that conventional is the middle class although the caveats of vulnerability.

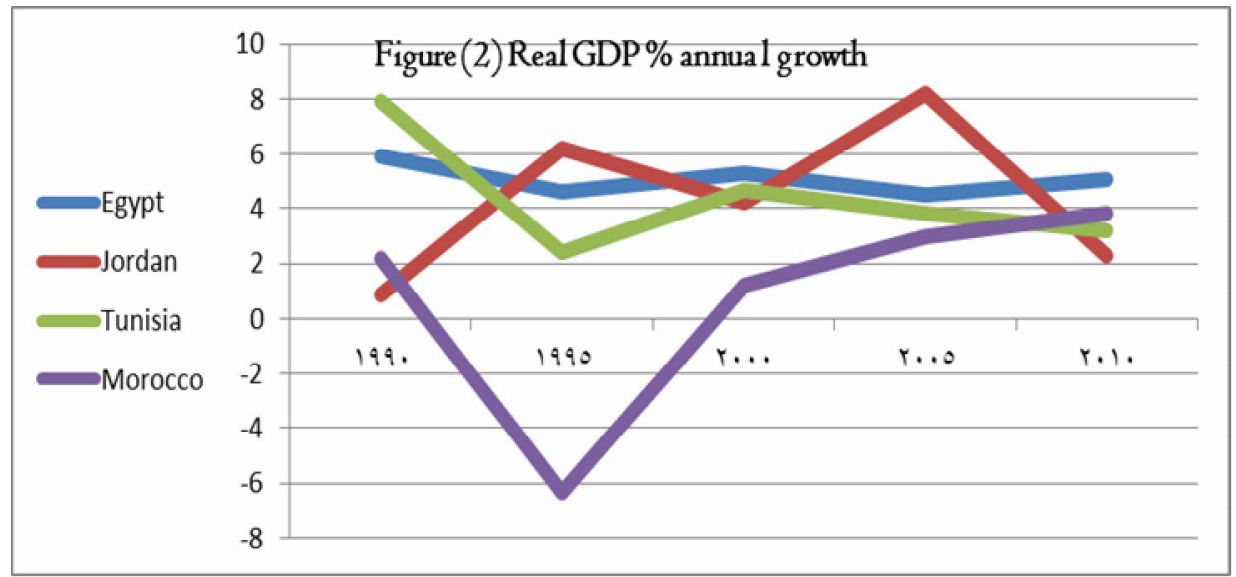

Source: world development indicators 2015

Considering the distribution of income by quintiles as shown in the following four figures, changes in the distribution of quintile expenditure over the five waves of the four countries were limited to all quintiles over time. However, the low 20 percent share remained unchanged in Morocco, while in Egypt the richest share increased by 1.04 percent), while shares of all other quintiles rose slightly. In Jordan and Tunisia, the share of the poorest quintile developed to some extent. It is worth noting that the distribution of income during the emerging surveys (1990-2010) did not change significantly in response to the economic downturn as presented in Figure (2). 


\section{Dr. Abeer Mohamed Ibrahim Rashdan}

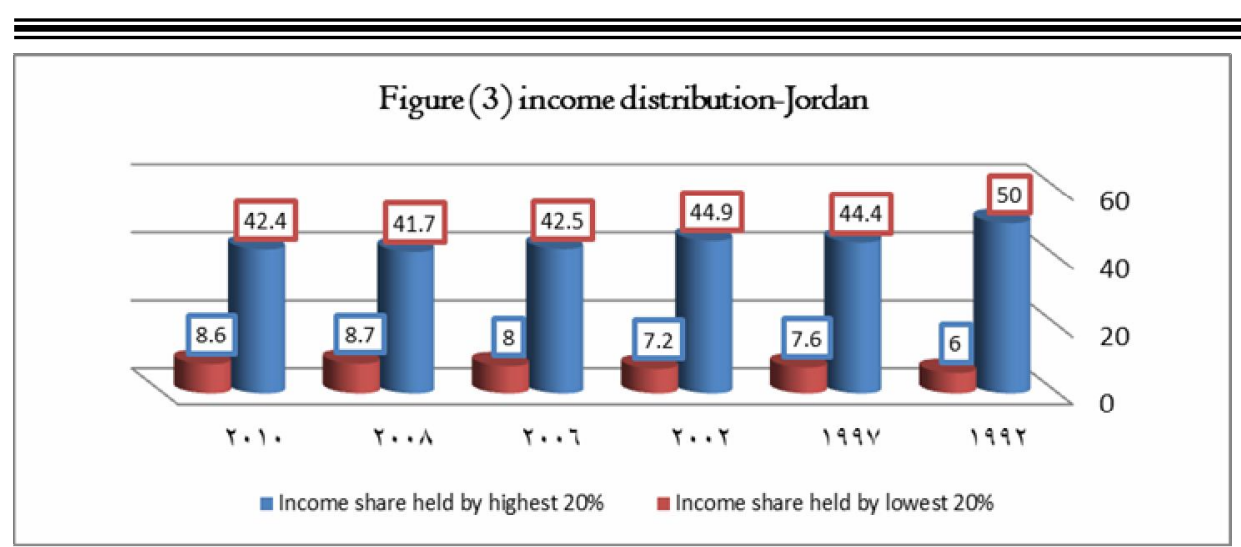

Source: Povcal, world bank data

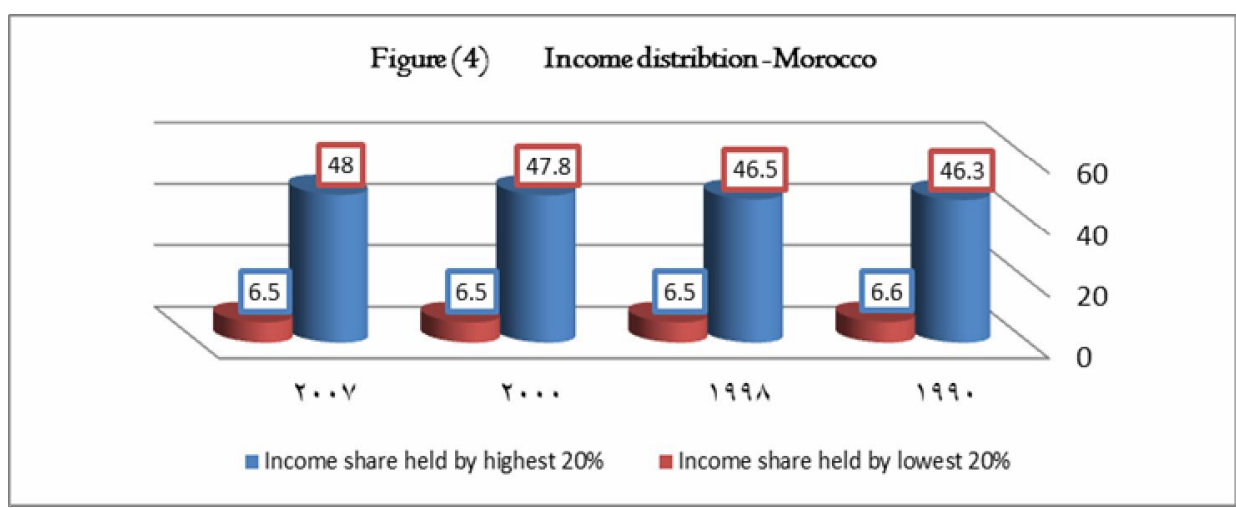

Source: Povcal, world bank data

Figure (6) Income distribution- Egypt

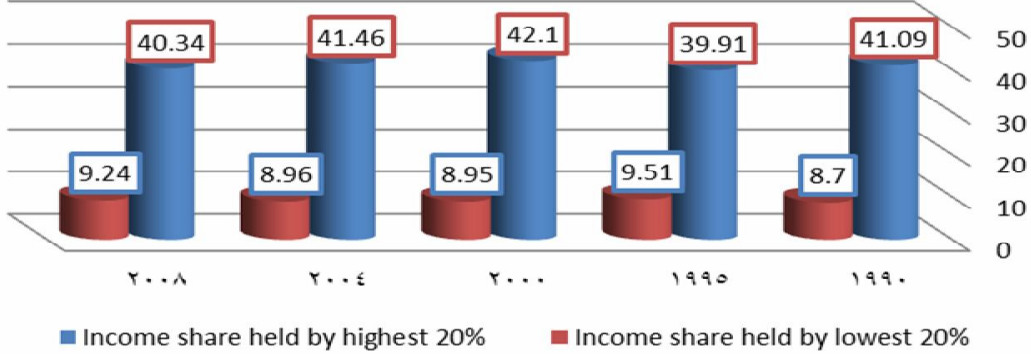

Source: Povcal, world bank data 
Scientific Journal for Financial and Commercial Studies and Researches

(SJFCSR) Faculty of Commerce - Damietta University

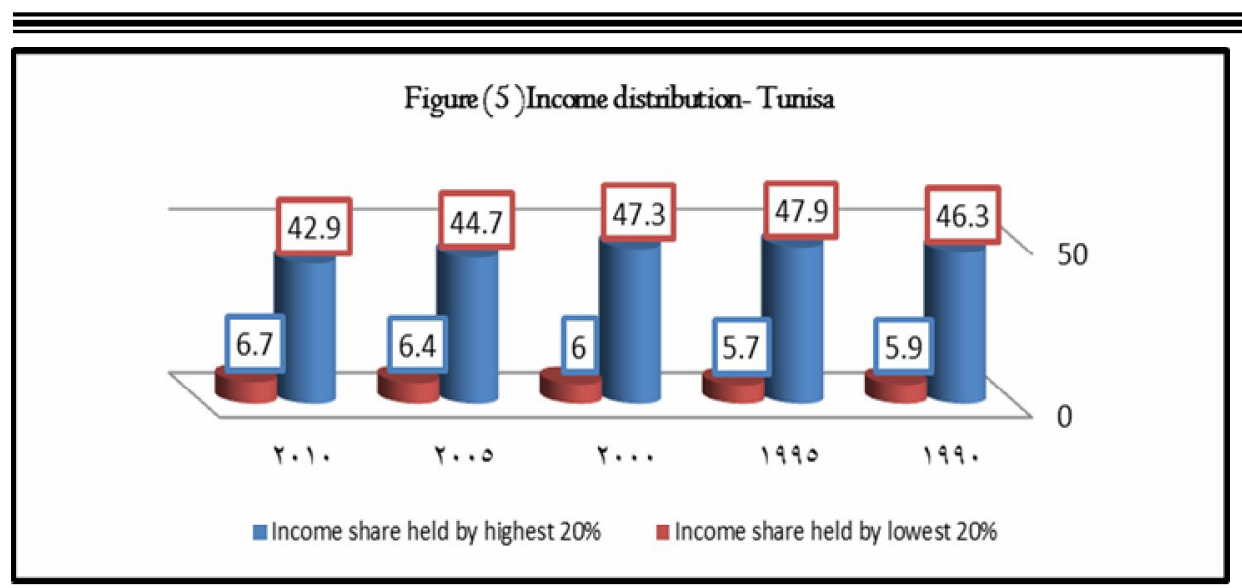

Source: Povcal, world bank data

\section{Section Three: Data and Methodology}

Data for measuring the evolution size of $\mathrm{MC}$ is primarily from the povcal database, considering that used poverty database according to the available survey for each country. Regarding the social outcome, health, education, and tariff are mainly form the world development indicators 2017. Also, the evolution of economic development and its effect on the other variables, GDP per capita was used as a proxy of economic growth, as for institutional aspects the research uses the governance subindicators (rule of law, corruption, and democracy) all these indicators during the period under study (1990-2015).

\subsection{Empirical Methodology}

To calculate the size of MC using a fixed line $(\$ 4-\$ 13)$ as an absolute method. And then the effects of MC size on expenditure pattern and institutional changes as well as policies regarding three categories: social policy regarding to health care and education costs, marketoriented commercial and financial policies, and quality of governance (including democracy and corruption). A group of regression models are applied to associate each result of each variation of the descriptive variables. Where the following is the regression model is:

$$
y_{i, t}=\mu_{t}+\gamma_{i}+\hat{\beta} x_{i, t}+\epsilon_{i, t}
$$




\section{Dr. Abeer Mohamed Ibrahim Rashdan}

where $\mathbf{y}$ represents a given policy outcome, $\mathbf{x}$ is a group of explanatory variables that include the size of the middle class, $\gamma$ is an unobserved country-specific effect, $\boldsymbol{\mu}$ is time-specific effect, and $\boldsymbol{\varepsilon}$ as a regression residual. The subscripts $\mathbf{i}$ and $\mathbf{t}$ represent country and time, respectively. This estimation draws from mixed effect model for the panel data. In panel data context this type of models is known as "mixed effect models" where the variables of the study (Explanatory variables) GDP per capita, Middle class number. Dependent variables; rule of law, Government effectiveness, Corruption, Health, Tariff, and education.

\subsection{Empirical Results}

In same line of most literature where GDP per capita represents a country's economic development s (Easterly and Levine; 2003; Acemoglu, Johnson, and Robinson, 2001). As expected, GDP per capita is positively correlated with the size of MC. In table two which shows the significant correlation between the economic development and the size of $\mathrm{MC}$ in the four countries.

\section{Table (2) Correlation between GDP and Middle Class}

\begin{tabular}{|l|l|l|l|}
\hline & & \multicolumn{1}{|c|}{ GDP per capita } & Middle class \\
\hline Jordan & GDP per capita & 1 & \\
\hline & Middle class & $0.9681^{* * *}$ & 1 \\
\hline Tunisia & GDP per capita & 1 & \\
\hline & Middle class & $0.8947^{* * *}$ & 1 \\
\hline Morocco & GDP per capita & 1 & \\
\hline & Middle class & $0.6797^{* * *}$ & 1 \\
\hline Egypt & GDP per capita & 1 & \\
\hline & Middle class & $0.9480 * * *$ & 1 \\
\hline
\end{tabular}

\section{Social - Political outcomes and economic development}

To look at the relationship between economic development, social and political institutional outcomes in Table 3. Numerous evidences came out that policies and institutions have a strong impact on economic development (Barro, 1991; Easterly and Levine, 2001; Chang and 
Scientific Journal for Financial and Commercial Studies and Researches

(SJFCSR) Faculty of Commerce - Damietta University

Loayza, 2009). Unfortunately, the selected countries didn't follow this conventional pace.

Table (3) GDP effect of social and political development

\begin{tabular}{|l|c|c|c|c|c|c|}
\hline & $\begin{array}{l}\text { Rule of } \\
\text { law }\end{array}$ & $\begin{array}{l}\text { Government } \\
\text { effectiveness }\end{array}$ & corruption & health & tariff & education \\
\hline $\begin{array}{l}\text { GDP per } \\
\text { capita }\end{array}$ & $\begin{array}{c}0.004025 \\
{[0.27]}\end{array}$ & $\begin{array}{c}-0.0069181^{* * *} \\
{[-3.77]}\end{array}$ & $\begin{array}{c}-0.0057^{* *} \\
{[-2.314]}\end{array}$ & $\begin{array}{c}0.00054^{* *} \\
{[2.51]}\end{array}$ & $\begin{array}{c}-0.013^{* * *} \\
{[-5.39]}\end{array}$ & $\begin{array}{c}-0.00026 \\
{[-1.52]}\end{array}$ \\
\hline Observations & 60 & 60 & 60 & 60 & 60 & 60 \\
\hline $\begin{array}{l}\text { Number of } \\
\text { countries }\end{array}$ & 4 & $4 \mathrm{e}$ & 4 & 4 & 4 & 4 \\
\hline
\end{tabular}

1. Z statistics in brackets

2. $* * * \mathrm{p}$-value $<0.01, * * \mathrm{p}$-value $<0.05, * \mathrm{p}$-value $<0.1$

The empirical results shows that GDP per capita has no significant relation with rule of law and education and this with confident $95 \%$ and this apply for the four Arabic countries. GDP per capita has significant positive relation with health, with confident $95 \%$ for the selected four Arabic countries. While GDP per capita has negative influence on each of government effectiveness and tariff this with confident $99 \%$, and a significant negative influence on corruption with confident $95 \%$ for the four Arabic countries.

Strong middle- class outcomes; according to Loayza et al (2012), the growth of the middle class has a major impact on social policy by attracting increasing public and health spending as shares in GDP. A larger section does not mean that the economy is largely run by the government. In contrast, the increase in the size of the middle class presents a market-focused economy by reducing prices in international trade and liberating the financial sector. The expansion of $\mathrm{MC}$ results in improvements in democracy and a reduction in legal corruption. In fact, this is not the case with the Arab countries that are being studied, although the $\mathrm{MC}$ explosion in these four countries is suffering from social and political consequences. 


\section{Dr. Abeer Mohamed Ibrahim Rashdan}

Table (4) Middle class effect on social -political development

\begin{tabular}{|l|c|c|c|c|c|c|}
\hline & $\begin{array}{c}\text { Rule of } \\
\text { law }\end{array}$ & $\begin{array}{c}\text { Government } \\
\text { effectiveness }\end{array}$ & Corruption & health & tariff & $\begin{array}{c}\text { educatio } \\
\text { n }\end{array}$ \\
\hline Middle class & -0.1798 & $-0.276^{*}$ & -0.1966 & $-0.0622^{* * *}$ & $-0.493^{* * *}$ & $-0.041^{* * *}$ \\
{$[-1.62]$} & {$[-1.95]$} & {$[-1.04]$} & {$[-3.89]$} & {$[-4.81]$} & {$[-5.18]$} \\
\hline Observations & 60 & 60 & 60 & 60 & 60 & 60 \\
\hline $\begin{array}{l}\text { Number of } \\
\text { countries }\end{array}$ & 4 & 4 & 4 & 4 & 4 & 4 \\
\hline
\end{tabular}

\section{Z statistics in brackets}

4. $* * * \mathrm{p}$-value $<0.01, * * \mathrm{p}$-value $<0.05, *$ p-value $<0.1$

In a striking result, middle class has negative influence on each of health, tariff, and education this with confident 99\%; and negative influence on government effectiveness on with confident $90 \%$. Also, MC in the four countries has no significant impact e on rule of law and corruption.

\section{Conclusion:}

According to the study there is a clear evidence of bulging of $\mathrm{MC}$ for the four Arab countries, consisting with the most of strand of literature that proved the steadily bulging of $\mathrm{MC}$ in the Arab region, that would eventually create an appropriate social and political element for economic development improvements that would lead to reform the government policies and institutions. In contrary the results find that when the size of the middle class increases, measured by fixed approach between (\$4 -\$13) per day, the social and economic outcomes measured by expenditure on education and health, in addition to the quality of governance regarding rule of law, government effectiveness and corruption didn't follow the expected outcomes. Middle class followed the conventional results of its positive correlation with GDP per capita, however, the social and political aspects did not improve, and Middle class in the four countries has negative influence on each of health, tariff, and education and negative influence on government effectiveness. Middle class has no significant influence on rule of law and corruption. This entail reviewed of the economic and social policies for these countries. Policies should be used to help the growing population of the poor- social mobility, considering the political aspect that could prevent many of the economic policies that have been implemented. 
Scientific Journal for Financial and Commercial Studies and Researches

(SJFCSR) Faculty of Commerce - Damietta University

\section{$\underline{\text { References }}$}

- Acemoglu, D., Johnson, S., \& Robinson, J. A. (2001). The colonial origins of comparative development: An empirical investigation. American economic review, 91(5), 1369-1401.

- Acemoglu, D., Johnson, S., Robinson, J. A., \& Yared, P. (2008). Income and democracy. American Economic Review, 98(3), 80842 .

- Acemoglu, D., Johnson, S., Robinson, J. A., \& Yared, P. (2009). Reevaluating the modernization hypothesis. Journal of monetary economics, 56(8), 1043-1058.

- Arellano, M., \& Bond, S. (1991). Some tests of specification for panel data: Monte Carlo evidence and an application to employment equations. The review of economic studies, 58(2), 277-297.

- Arellano, M., \& Bover, O. (1995). Another look at the instrumental variable estimation of error-components models. Journal of econometrics, 68(1), 29-51.

- Banerjee, A. V., \& Duflo, E. (2008). What is middle class about the middle classes around the world?. Journal of economic perspectives, 22(2), 3-28.

- Barro, R. J. (1999). Determinants of democracy. Journal of Political economy, 107(S6), S158-S183.

- Birdsall, N. (2010). The (indispensable) middle class in developing countries; or, the rich and the rest, not the poor and the rest. EQUITY IN A GLOBALIZING WORLD, Ravi Kanbur and Michael Spence, eds., World Bank, Forthcoming.

- Easterly, W. (2001). SESSION 2A: VALUES AND ECONOMIC GROWTH: The Middle-Class Consensus and Economic Development. The Journal of Economic History, 61(2), 518-518.

- El-Laithy, H., Lokshin, M., \& Banerji, A. (2003). Poverty and economic growth in Egypt, 1995-2000. The World Bank. 


\section{Dr. Abeer Mohamed Ibrahim Rashdan}

- Goldthorpe, J. H., \& McKnight, A. (2006). The economic basis of social class. Mobility and inequality: Frontiers of research in sociology and economics, 109-136.

- Graham, C., Pettinato, S., \& Birdsall, N. (2000). Stuck in the Tunnel: Is Globalization Muddling the Middle Class? (No. 277). LIS Cross-National Data Center in Luxembourg.

- Kharas, H. (2010). The emerging middle class in developing countries.

- Milanovic, B. (2011). Global inequality: from class to location, from proletarians to migrants. The World Bank.

- Ravallion, M. (2001). Growth, inequality and poverty: looking beyond averages. World development, 29(11), 1803-1815.

- Ravallion, M. (2009). The developing world's bulging (but vulnerable)" middle class". The World Bank.

- Ravallion, M., \& Datt, G. (2002). Why has economic growth been more pro-poor in some states of India than others. Journal of development economics, 68(2), 381-400.

- UNESCWA (2015), Measurement and role in driving change "The Arab millennium development goals. 
Scientific Journal for Financial and Commercial Studies and Researches (SJFCSR) Faculty of Commerce - Damietta University

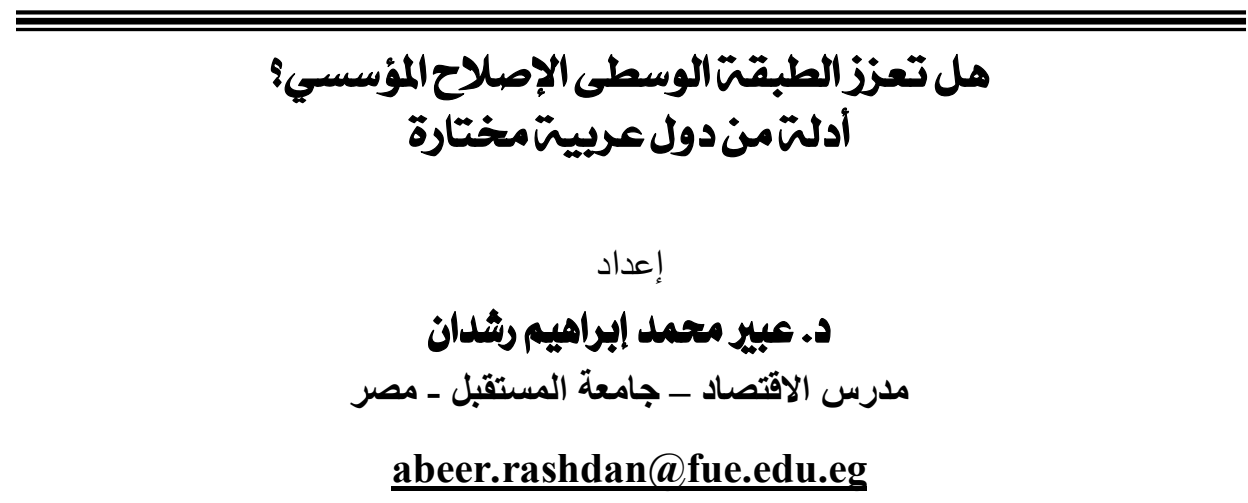

ملخص الدراستّباللغت العربيت:

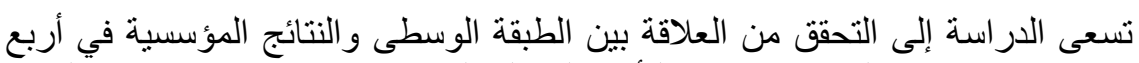

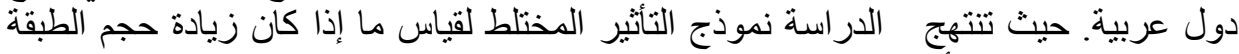

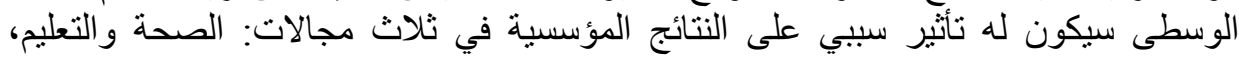

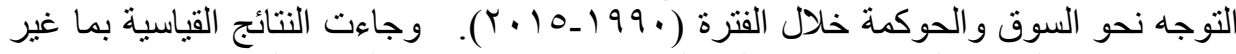

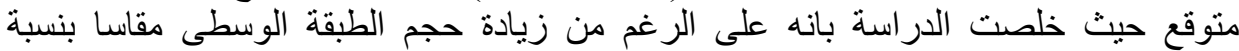

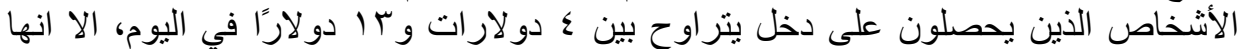

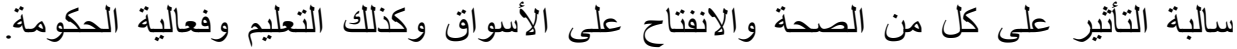

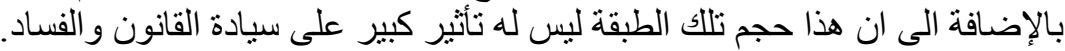

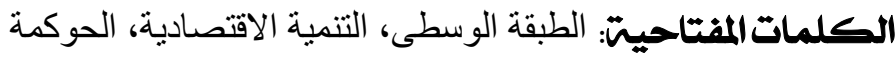

